\title{
Corina DOMINTE*
}

\section{THE CENSORSHIP OF BOOKS IN THE LIBRARY OF “S,TEFAN CEL MARE” NATIONAL COLLEGE FROM SUCEAVA $(\mathbf{1 8 6 0 - 1 9 9 0})^{1}$}

\begin{abstract}
This paper aims at presenting the censorship of books and documents at the library from the first high school from southern Bucovina Griechisch-orientalische kaiserlich-königliche Obergymnasium in Suczawa, a typical high school in which German was the tuition language, founded by imperial decree on the 30th of June 1860, today known as Colegiul Național "Ștefan cel Mare" from Suceava. This study is based on original archive documents, previous studies on the topic and documents from the school library. Relying on historical research approaches, the phenomenon of book censorship is analysed during all political regimes that succeeded in the nearly 160 years of existence of the school library. The paper points out to the restrictions imposed during the Austrian rule (1860-1918), the cleansing and even destruction of the most valuable books belonging to the Romanian heritage during the totalitarian regimes after the Great Union of 1918, the reorganization of the special collections, the restriction of the public accessibility to certain titles. This paper, alongside previous ones on the same topic, is meant to contribute to the understanding of the complex phenomenon of censorship in Romanian libraries.
\end{abstract} Bucovina

Keywords: book censorship, school library, secondary education,

\section{Introduction}

The censorship of the written word emerged at the same time as the Gutenberg's invention and has manifested itself in different forms throughout centuries, varying according to the political regime in power. After the Second World War, and especially after the abolition of monarchy on the $31^{\text {st }}$ of December 1947, censorship in Romania reached a peak, its full impact being still unknown.

\footnotetext{
* Faculty of History and Geography, "Ștefan cel Mare" University of Suceava, Romania; corina_dominte@hotmail.com. 
The library of the first high school in southern Bucovina - Griechischorientalische kaiserlich-königliche Obergymnasium in Suczawa, today's Colegiul Național "Ștefan cel Mare", founded by imperial decree on the $30^{\text {th }}$ of June $1860-$ faced the phenomenon of censorship during its almost 160 of existence.

As far as we are concerned, although all libraries in Romania were checked and verified after 1944, evidence regarding the cleansing of these cultural establishments is still relatively slim 30 years after the fall of the communist regime. The bulk of the works published refers to organisational data or "censorship of literary works, and more rarely to that of the press or other forms of public events" (Petcu 2016: 7).

The issue of eliminating books from loans was tackled by Liliana Corboca in a paper entitled Controling Books. Censorship of Literature in Romania during the Communist Regime (2014, Bucuresti: Cartea Românească), and in the monography Cleansing of Books in Romania (2010, București: Tritonic), the same author published unusual evidence, representative for the process of book cleansing between 1944-1964. In 2000, Paul Caravia published Forbidden thinking. Censored written works. Romania 1945-1989 (București: Editura Enciclopedică). Studies related to the process of cleansing libraries were presented by Ionuț Costea, István Kiraly and Doru Radosav in Secret Fund. Fond " $S$ " special - Contributions to the History of Library Secret Funds in Romania. Case study. Central University Library "Lucian Blaga" Cluj-Napoca (1995, Cluj-Napoca: Dacia) and by Carmen Bădură in the paper Censorship in the Libraries from Iasi during the Communist Regime. Case Study - Books in the Secret Fund of the County Library "Gheorghe Asachi" Iasi and the Central University Library "Mihai Eminescu" from Iasi (2015, Iași: Historia Universitatis Iassiensis VI, 243-275). In 2013 Roxana Bălucă gets her PhD with a paper entitled Censorship in the Central University Libraries in Romania during the Communist Regime at the University "Babeș-Bolyai" from Cluj-Napoca.

\section{Restrictions Imposed on the Library during the Habsburg rule} (1860-1918)

The policy of book purchase for the libraries from the secondary schools in the Austrian Empire was very strictly controlled by the government from Vienna. Decree nr. 315 from the $12^{\text {th }}$ of July 1875 , followed by decision 13456 from the $3^{\text {rd }}$ of January 1882, forbade books which may have degraded respect for religion, attachment towards the dynasty, patritic feelings and respect for state run institutions. The purchase of books was made on approval from the teaching staff, according to the needs put forward by each of the school teachers, according to article 55 from the organisational plan of education in the Austrian Empire, enforced 
on the $15^{\text {th }}$ of September 1849 and implemented between 1851-1857 (Popovici 1935: 25). "Trustworthy" students were exceptionally allowed to access books from the teachers' library, only with the permission of the headteacher (Consiliul Școlar al Țării 1918: 312), and the students' readings were established during conferences of the teching staff and had to be periodically assessed by the techers, "in written form as well" (Ministerium für Cultus und Unterricht Wien 1883: 6). Book purchases and donations were supposed to be published in the school's yearly book. Beginning with 1875, all the secondary schools from the Austrian educational system were obliged to publish the source of the purchase as well, according to ministerial decision nr. 8710 from the $9^{\text {th }}$ of June (Grassauer 1883: 18).

The library of the first high school from southern Bucovina - The GreekOriental Upper Secondary Gymnasium from Suceava was organised and run between 1860-1866 by the first school principal, dr. Josef Marek, teacher of classical studies. It was Dr. Marek who made the first book purchase in 1860, by "telegraph order" from Vienna, as in Suceava there "was no library" and in Cernăuți all the "necessary teaching materials" were out of stock on the $16^{\text {th }}$ of September (Popovici 1935: 24).

At the conference of the teaching staff which took place between the $18^{\text {th }}$ $30^{\text {th }}$ of October 1860 , the list of necessary teaching books for the first year of academic activity of the new establishment was submitted for approval. Drawn up by headteacher Marek together with the schoolteachers, the list of 48 book titles necessary for the study of the subjects in the curriculum was to be approved by the Court in Vienna. (Grassauer 1883: 194).

For the study of Romanian language, the first Romanian teacher, catechist Constantin Andrievici asked for 71 titles of Romanian books: 16 of them were from the "religious, church domain", nine titles belonged to the domain of "morality, especially for young learners", nine "secular history" titles, four "geographical" ones, 15 titles of poetry volumes, three philosophical ones, four of "physics and natural history" and seven "linguistics and grammar books" (Morariu 1889: 16-20). Only four titles of those submitted were accepted - Lexicon by Baritiu, Lexicon by I. Eliade, German-Romanian Grammar by V. Ianoviciu, Grammar by Munteanu. As the bookshop Gerold's Sohn from Vienna had none of the requested Romanian titles and Winiarz bookshop from Cernauti only had one, headteacher Marek asked teacher Andrievici another list of book titles for the study of Romanian, and this time it was drafted in German (Morariu 1889: 26). The new, ampler catalogue, drawn up by Constantin Andrievici in Romanian, and put forward during the conference of the teaching staff that took place between January $28^{\text {th }}$ and February $9^{\text {th }} 1861$, comprised 124 titles of Romanian books, listed under two headings: 54 books aimed at "promoting the study of Romanian during the four years of lower 
gymnasium" and 70 "meant to widen the knowledge of Romanian language and literature at the upper gymnasium classes" (Morariu 1889: 27-35). Besides fables, ballads and poetry by Alecsandri, Văcărescu, Asachi, Bolintineanu or Anton Pann, on Constantin Andrievici's list one can find Lexicons and grammar books by Ianovici, Munteanu and Bellissimus alongside the request for purchasing Kogalniceanu's Yearly Books, The History of Țara Românească and Moldova, illustrated with portraits of Moldavian and Romanian rulers in two volumes (Morariu 1889: 25).

Due to the existing situation, the library with Romanian books for the students of the gymnasium from Suceava was housed in Constantin Andrievici' own home (Morariu 1889: 37). His initiative benefitted from the support he got from authors and printing houses from the Romanian Principates in the form of "books and publishings for the Romanian schools and libraries from Bucovina", in the wake of the appeal launched by the Romanian government in 1861 (Nistor 1991: 149). The book collection in Romanian was first clandestine, being very popular among "the studious youth" on Sundays and on religious holidays. Having been promoted to the position of professor of morale and dogma at the the Greek-Oriental Theological Institute from Cernăuţi, in 1869 (Popovici 1935: 33), Constantin Andrievici left "113 titles, mainly in Romanian, in 199 volumes" for keepsaking to the religion teacher Ion Beldean. He had collected the books while a "catechist of the gymnasium for Romanian students". In 1872, on leaving the school, teacher Beldean donated the books to the school library (Limberger 1872: 71).

The lack of Romanian teaching books led to another major issue that the teachers had to deal with until the 1918 Union. A high school that had been set up with tuition in Romanian, according to the imperial decision from the 20th of July 1859, for the majority Romanian population from Bucovina and financially backed by the Church Fund (Popovici 1935: 21-22, 24-48), the Greek-Oriental Upper Gymnasium from Suceava was for 21 years a classical high school with tuition in German. Only religion and Romanian language, which "was compulsory to all students", were taught in Romanian (Burduhos 1938: 25).

Statistic tables of the students published in the school's yearly books, show a decline in the number of Romanian students enrolled in the high school from Suceava up to 1881. In 1881, the first class taught in Romanian was set up by ministerial decree issued on the 7th of June 1881 and imperial decision dated February the 4th 1882 (Popovici 1935: 57). The postponement of organising Romanian classes at the high school from Suceava for two decades was explained as resulting from the "lack of well written textbooks" (Popovici, 1935: 94) as well as lack of Romanian speaking teachers. To ensure the maintenance of the classes in Romanian, teachers Ștefan Ștefureac, Samuil Isopescu and Animpodist Dașchievici 
wrote textbooks in Romanian, after the Austrian curriculum. "Due to unfavourable censorship, which was officially expressed", the teaching board approved only for the year 1896/97 the following textbooks: Tacitus - Latin Grammar, Neagoe - The Grammar of Romanian, Bou - Course of Grammar Exercises for Latin, asking the headteacher "in no uncertain terms" to put forward concrete proposals for the teaching of those subjects (Popovici, 1935: 95-96).

Set up only for the lower high school classes, the forms in which tuition was in Romanian were doomed to disappear. In order to carry on these classes to the upper courses, Romanian teachers had to write or to translate textbooks into Romanian. The validation commission established by the education ministry within the Educational Council of Bucovina was entitled, beginning with 1903, to grant approvals for school textbooks meant for the classes that had tuition in Romanian. The manuscripts of the teaching materials, however, were supposed to obtain the final approval only from The Ministry of Education and Cults from Vienna. In this respect, here is what teacher Eusebie Popovici wrote down:

Many manuscripts remained unprinted, as they were not ready prior to the ministerial approval [...] This happened to Reading Books for the lower course classes, published between $1910-1913$ by Eusebie Popovici, who had been urged to prepare them by the validation commission, which granted him approval as well. In 1914, the ministry from Vienna refused to give these books final approval and only disclosed the reason to the teaching staff, on grounds that these books only promote readings from the history of the Romanians, totally overlooking the history of the governing Austrian fatherland. Another fault found with these books was that they comprised too much from N. Iorga's writings, a "staunch and outspoken adversary of Austria". These books may well have been removed from tuition, unless the events and turmoil of war had not weakened the government's surveillance (1935: 97-98).

Romanian textbooks written by Eusebie Popovici for forms VII-VIII also remained in manuscript form, although they had received favourable approval (1913) from the validation commission. The ministry of education from Vienna returned them to the author (1915) to be completed with patriotic readings [Austrian ones] "which by no means could be omitted" and which were unknown to Romanian speakers (Popovici, 1935: 99).

Organising classes with tuition in Romanian at the upper classes of high school meant the victory of the Romanian school principals and teachers and mainly the victory of the students from grade VIII in 1906, whose former teacher was Ion I. Nistor, a historian, teacher at the gymnasium between 1904-1907. The class was 
assessed in German by the school inspector who had come for this purpose from Cernăuți. Among the graduates of this class it is noteworthy mentioning Ioan Bilețchi, who was to become the school principal at high school "Dragoș Vodă" from Câmpulung Moldovenesc in the mid war period, Ion Grămadă - the hero from Cireșoaia, Dimitrie Marmeliuc - a voluntary in the Romanian army, wounded in the battles from Mărășești, Alexandru (Leca) Morariu - a university professor and publisher (Repta 1906: 1-2, 33).

\section{Censorship of the library in the mid-war era}

The war had borne a brunt on the book collection for the students at the gymnasium from Suceava. The removal of the books which "favoured in content the Austrians" during the Russian occupation (1916-1918) reduced the number of books to 584 titles - 67 Romanian and 517 German. When the Russians left, there was almost "no library" for students and it was "in no order whatsoever" (Burduhos 1922b: 32). Reorganised from scratch after the war (Burduhos 1922a: 12-13) for the opening of the school year 1918-1919, the School Council of the Country within The Administration of Bucovina, requested through order nr. 4203/1919 from the $21^{\text {st }}$ of January 1920, a new revision of the library, as it had been founded "according to the demands of the Austrian rule". All the books that did not correspond "from a pariotic, moral and religious perspective" and all the history and geography books "written in order to promote the idea of an Austrian state and with a view to raising our youth for this state". The report and the subsequent inventory signed by the school principal and the members of the validation commission, alongside explanations for each title, were to be submitted to the Council by the $1^{\text {st }}$ of July 1920. For the purchase of new titles, the same procedure was applied, and the books which were not "fully consistent with the above mentioned requirements", were not to be on purchase before the end of the checking (Consiliul Școlar al Țării 1919b: 53).

The issue of school textbooks at the beginning of the school year 1918-1919 had not been solved by the next school year (Burduhos 1919: 4). For the united countries, textbooks for all the school subjects had been multiplied, comprising "essential changes resulting from the union". Textbooks which "did not infringe on the reality of the political union" ran out of stock, as did those reprinted which comprised "special references to the national war", the ones which did not comply being removed, and the ones to be printed were to be drafted "according to the unitary analytical curriculum" (Secretariatul de Serviciu pentru Instrucțiunea Publică 1919: 15-22). 
Teaching history and geography encountered difficulty due to the lack of maps, "mainly for the Romanian territories" (Burduhos 1919: 4). On November 28th 1920, The School Council of the Country from the Administration of Bucovina, sent the order nr. 13077/1920 which banned the the history and geography textbooks printed before the war. These textbooks had to be "adapted to the new realities" (Consiliul Școlar al Țării 1920: 550). History and geography were taught according to a modified curriculum, in compliance with the secret state order for education, nr. 32 from the $17^{\text {th }}$ of December 1918 (Burduhos 1919: 4). The teachers of those subjects had to acquaint themselves as quickly as possible with the textbooks coming from the old kingdom, written by Clinciu-Dimitrescu, Aguletti, Iorga, Mehedinți-Durcă, Zaharescu and others. The geology of Austro-Hungaria was replaced with the geology of the Romanian countries (Consiliul Școlar al Țării 1919a: 274).

A further revision of the books in stock was made in December 1922. Books with "inappropriate content" were withdrawn and handed to the teacher by the librarian, to be read during the holiday. Approval for reading the books which had been eliminated was to be noted by each teacher in the inventory of the students' library, under signature (Burduhos 1922a: 12-13). On the $30^{\text {th }}$ of June 1923, not all the books taken from the students' library "to be censored" had been returned (Burduhos 1923: 48). From the students library had been withdrawn a volume of short stories entitled A Woman's Soul written by A. Braniște, deemed as "inappropriate on the reading list for students", according to the order issued by the Regional Inspectorate XIV from Cernăuți nr. 25327 dated the $8^{\text {th }}$ of December 1927 (Inspectoratul regional XIV Cernăuți 1927: 1017).

The change in political regime which occurred on September $5^{\text {th }}, 1940$ afflicted libraries, too. Forbidding access to books written by writers with Jewish background meant the debut of the cleansing of the public libraries under the Antonescu regime. On October $12^{\text {th }} 1940$, the ministry put a ban on the purchase of books published by Jewish publishing houses, such as Socec or Alcalay. The purchases were to be made only through the School Committy from Romanian book shops or book shoppers (Direcția Învăţământului Secundar 1940a: 667). In compliance with another order from the ministry, issued on October $18^{\text {th, }} 1940$, Christian students could buy school textbooks and stationery only from christian bookshops, Romanian publishing houses could not sell textbooks to Jewish bookshops and christian authors of school textbooks could not sign contracts with Jewish publishing houses (Direcția Învățământului Secundar 1940b: 686).

Book purchases during this period of time were mostly from The Publishing House of Graphical Arts and Bookshop Cartea Românească București (Editura Cartea Românească 1941a: 227), from "Bucovina" Publishing House from 
București, run by scholar Ilie E. Torouțiu and from Publishing House Casa Școalelor. The book entitled The History of Modern Philosophy. Homage to I. Petrovici, published by The Romanian Society of Philosophy, purchased on February 22 1941 (Editura Cartea Românească 1941b: 118), was removed in 1961.

As libraries were supposed to "contain only books that are useful for study and literature books", The Directorate for Teaching and Cults from Cernăuți required that all libraries be carefully checked and that all books with political content be eliminated, as stated in order nr. 129191/B/1942 issued by The Ministry for National Culture, made public on the 24th of July 1042 (Ieșan 1942: 24). Riddance of geography books by N. Pandele, due to their inappropriate content in the given period of time and compulsory subscription to "Monitorul Oficial" were ordered by the ministry on the 9th of November 1942 (Vișan 1942a: 63).

The inventory and a quick, initial sorting of the books in the main library and the class libraries was to be made between November $24^{\text {th }}-$ December $1^{\text {st }} 1942$, in compliance with the order nr. 42928/1942, issued by the Directorate for Teaching and Cults Cernăuți. All the works published by Jewish authors as well as the "frivolous ones, those unuseful or damaging" by other authors had to be removed. The same was applied to translations from foreign languages. Valuable reference books by any author could be kept, such as The Crestomathy by Gasteer, The Dictionary of the Romanian Language by Candrea and Adamescu. The books removed from libraries had a separate inventory and were kept at the disposal of the ministry, as the libraries were to be checked by representatives of the Office. The libraries were checked on class criteria, the books being carefully selected, at the form teacher's and class teachers' recommendation. Book donations which had not been revised by the form teacher were not allowed. The office drew up a list of compulsory books for each class library, and the high school was supposed to send, for a permanent exhibition, the latest issue of the school's magazine, in order to "support those good and useful ones" (Vișan 1942b: 133). Lists nr. 1a and 1b received from the mayor of Suceava on the $11^{\text {th }}$ of December 1942 contained "names of some Jewish authors", whose works "were totally forbidden", libraries being expected to remove them from their inventory (Primăria Orașului Suceava 1942: 205).

Here is the situation of the libraries of the Boys' High School "Ștefan cel Mare" Suceava on the $31^{\text {st }}$ of March 1943, according to the report nr. 3534/1943 put forward by principal Ienceanu: the teachers' library had 10324 volumes and there were no volumes removed; class libraries had 3426 volumes, out of which 3 volumes were removed, on the date of the report remaining 3423 volumes (Ienceanu 1943a: 171; 1943b: 183). Thus, at the end of the school year, an increase of over 
1000 volumes were recorded, for both teachers' and students libraries (Ienceanu 1943c: 3).

Financially, the school year 1943-1944 could not be reported as the school had been evacuated at the end of March 1944. On leaving the school premises, the teaching staff left behind a building "thoroughly" renovated with funds from The Government of Bucovina, a rich and recently renewed mobile inventory with a "powerful radio transmitter with speakers, amplifiers and microphne", a valuable library from which only 100 volumes had been removed and three carriages of wood, fuel for the winter (Cărăușu 1945a: 8). Returning alone from Slatina, Olt county, on the $6^{\text {th }}$ of January 1945, principal Vasile Ienceanu found the building intact, with little loss as to teaching materials and furniture, and the losses at the library were to be assessed later (Cărăuşu 1945b: 2-3; Ienceanu 1945c: 32).

\section{Library cleansing between 1945-1947}

The acceptance of the truce offered by The Soviet Union, Great Britain and The USA on the $23^{\text {rd }}$ of August and the signing of the Truce Convention of the United Nations on the $12^{\text {th }}$ of September 1944, meant that Romania entered under Soviet domination. The cleansings initiated by the new regime dealt a tremendous blow to libraries as well.

On the $17^{\text {th }}$ of January 1945, all the maps in which "Basarabia and Northern Bucovina are shown within Romanian territory" are handed to the Suceava Police Headquarter, following the order issued by Central Military Censorship București nr. 1920/1944 (Ieremie 1945: 65). Student libraries were reorganised according to class, the form teachers having to revise the German books, and remove those which "in content do not comply with the country's political orientation" (Ienceanu 1945a: 6). On the 10th of February 1945, principal Vasile Ienceanu transmitted to the administrative head inspector from Suceava that he had checked the teachers' and the students' libraries and had eliminated "the books which in their content are harmful to our relationship with the United Nations [...] Adolf Hitler, Menin Kampf, München: Franz Eher Publishing House; Hanns Gosch, Wahn Europa, 1934, Hamburg-Berlin-Leipzig: Fackelreiter Publishing House" (Ienceanu 1945b: 121).

The office for truce within the Prefecture of the County of Suceava reminded on the $17^{\text {th }}$ of February that "all clerks who had been in Basarabia and had received books in any form from the deposits and libraries from Basarabia before July 1941 were expected to bring these books to the Prefecture before the $20^{\text {th }}$ of February 1945" (Prefectura Județului Suceava 1945a: 19).

On the $29^{\text {th }}$ of March 1945, "high school principal Vasile Ienceanu was arrested and detained for three months, the grounds for which this had been done 
being disclosed neither to him, nor to the school" (Cărăușu 1945b: 2-3). He was replaced by Aurel Buleandra, who announced the teaching staff, at the meeting held on the $13^{\text {th }}$ of April 1945, that "all the materials with fascist content had been long before removed, a fact that is going to be confirmed by the commission named by the Prefecture for the checking and verification of libraries" (Buleandră 1945: 1012).

The cleansing of the high school libraries continued throughout the year. The Office for the Application of the Truce within the Prefecture from Suceava sent on the $24^{\text {th }}$ of August 1945, the leaflet containing the publications withdrawn before the $1^{\text {st }}$ of August 1945, "so that the necessary measures be taken for strict compliance" (Prefectura Județului Suceava 1945b: 19). On the $28^{\text {th }}$ of August 1945, Suceava Townhall asked that "all the books, magazines, maps or various graphical or plastic reproductions which are at odds with the good relationships between Romania and The United Nations be removed", in compliance with the decisions from art. 3, 4 and 5 from Law Nr. 364/945, published in the Law Journal Nr. 102 dated the $4^{\text {th }}$ of May 1945 (Doroftei 1945: 16). Article nr. 4 of the law stipulated that the loan library, public libraries as well as the public institutions which deposit or possess in any form or under any title mentioned in article $\mathrm{nr} .2$, will immediately withdraw them and will deposit them in special rooms. Article nr. 5 mentioned that "as the lists will be published by the comission in the Law Journal [...] the public institutions where such publishings can be found will hand in the aforementioned publishings to the Prefecture of the county, within 30 days from the publishing of the list". The sanctions for the librarians who broke article nr. 7 consisted in, according to article nr. 8, correction imprisonment between 1-3 years or fine ranging from 50.000 to 100.000 lei (Ministerul Propagandei 1945: 3701-3702).

The teachers' library was checked according to lists nr. 9-13 comprising forbidden titles, at the order of The Ministry for Home Office, The Office for Documentation and Administrative Studies nr. 112.000 dated $23^{\text {rd }}$ of August 1945. On the $29^{\text {th }}$ of October 1945, librarian Reveca Slevoca announced the school board and Suceava Police that from the teachers' library from "Ștefan cel Mare" High School some books were going to be removed: Teofil Sidorovici - Brazda nouă [A New Furrow] [București: Tiparul Oltenia, 1939], Ilie Popescu-Teiușan - Spre o nouă educație a tineretului. Pedagodia comunităților de muncă [For a New Education of the Youth. Pedagogy of work communities] [second issue, Craiova: Scrisul Românesc Publishing House, 1943], captain pilot Oprea Gh. Petre - Pagini din istoricul aviației [Pages from the History of Aviation] [Craiova: Ramuri Publishing House] (Slevoca 1945: 391).

The process of elimination of "the books with a harmul effect on the good relationships between Romania and the United Nations" was closely monitored by 
the Regional School Inspectorate from Suceava. In request nr. 16124 sent to the school board on the $15^{\text {th }}$ of November 1945, the inspectorate demanded the statistics of the school library, mentioning the five previous requests "in which there was reference to the 6 book lists". Simultaneously, the school was to ask from the Prefecture the lists published later, "in addition to the 6 lists of books" (Ițcuș 1945: 598). Principal Mihai Cărăușu informed the superior authorities, in address nr. 677 from the $28^{\text {th }}$ of November that "the high school has a teachers' library and a students' library, organised on classes [...] the teachers' library having been endowed with 50 books from the stock of the School House in the school year 19431944" and has "an inventory catalogue on position and a catalogue with files (for the most commonly accessed sections)" and the forbidden publishings had been removed, in compliance with the regulations (Cărăuşu 1945d: 599).

As to the school library, "head teachers had the responsibility that the book cleansing be done thoroughly, according to the existing regulations", as specified in the order issued by The Ministry for National Education nr. 227018 dated the $14^{\text {th }}$ of September 1945 (Voitec 1945: 59, 61). The regulations sent by the ministry alongside this order forbade the introduction of foreign books or magazines of any kind, as well as the exchange, selling or purchase of books without the parents' consent (Cărăușu 1945c: 74).

The high school's libraries were checked once again in September 1946, in compliance with the order issued by the Ministry of National Education nr. $315143 / 1946$, transmitted with the order from the Regional School Inspectorate from Suceava nr. 16959/1946. For this, the councillor of the Suceava region from the Ministry of Information, alongside address nr. 198, two copies of the publications that had been removed (Grămadă 1946: 246-247). The minutes drafted on the $16^{\text {th }}$ of October 1946 mentioned that 76 old textbooks from the school students had been burned - 18 Romanian textbooks, 30 history textbooks and 28 geography textbooks (Grigorovici 1946: 139-143). 96 periodical and non-periodical publishings were withdrawn, according to table nr. 1 drafted by the high school commission president, principal Mihai Cărăușu, and other commission members, namely dr. Alexandru Bocănețu, Teodor Alaci and dr. Alois Grigorovici (Cărăușu 1946: 144-145).

\begin{tabular}{c|l|c}
$\begin{array}{l}\text { Nr. } \\
\text { crt. }\end{array}$ & \multicolumn{1}{|l}{$\begin{array}{c}\text { Nr. of } \\
\text { withdrawn } \\
\text { volumes }\end{array}$} \\
\hline 1. & $\begin{array}{l}\text { Revista Miorița [Miorița Magazine] [Literary magazine of the } \\
\text { guardians from Cernăuți, fortnightly, under the leadership of a }\end{array}$ & 34 \\
& $\begin{array}{l}\text { committee, "Viața Strejărească" Publishing House from } \\
\text { Cernăuți, first issue on the 15 } 15^{\text {th }} \text { of September 1938], Nr. 1- }\end{array}$
\end{tabular}




\begin{tabular}{|c|c|c|}
\hline & 2/1940 (18 vol.) and Nr. 5-7/1940 (16 vol.) & \\
\hline 2. & $\begin{array}{l}\text { Revista Tineretului [Tineretului Magazine] [issues in } 1943 \text { in } \\
\text { București, published by O.E.T.R. The Office of Education of } \\
\text { the Romanian Youth founded in } 1934 \text { in București] Nr. } 8 \text { (7 } \\
\text { vol.), Nr. } 7 \text { ( } 7 \text { vol.), Nr. } 6 \text { ( } 3 \text { vol.), Nr. } 5 \text { ( } 4 \text { vol.), Nr. } 4 \text { ( } 2 \text { vol.), } \\
\text { Nr. } 3 \text { (5 vol.), Nr. } 2 \text { ( } 5 \text { vol.), Nr. } 1 \text { (1 vol.) }\end{array}$ & 34 \\
\hline 3. & $\begin{array}{l}\text { Buletinul Straja Țării [The Bulletin of the Country's Guard], } \\
\text { nr.1/1940 }\end{array}$ & 8 \\
\hline 4. & $\begin{array}{l}\text { Leonte Dumitrescu, S-au desrobit Hotare Sfinte: versuri } \\
\text { [Borders Have Been Freed Holy: poems] [București: Institutul } \\
\text { de Arte Grafice al Muncei] }\end{array}$ & 1 \\
\hline 5. & $\begin{array}{l}\text { Leonte Dumitrescu, Cântarea biruinții [The Song of Triumph], } \\
\text { București, } 1942\end{array}$ & 1 \\
\hline 6. & Der jugend gute Brücher [The Youth Good Breaks], VI ${ }^{\mathrm{th}}$ grade & 1 \\
\hline 7. & Unseren Jungen [Our Boy], VI ${ }^{\text {th }}$ grade & 1 \\
\hline 8. & $\begin{array}{l}\text { Ioan N. Țuțianu, Din mijloacele folosite de Ungaria pentru } \\
\text { desnaționalizarea Românilor din Ardeal [From the Means used } \\
\text { in Hungary for the uprooting of the Romanians in Ardeal], } \\
\text { Bucuresti, } 1937\end{array}$ & 1 \\
\hline 9. & $\begin{array}{l}\text { I. C. Delaturda, Război şi civilizație [War and Civilisation] } \\
\text { [1922/29, Cluj: The Institute of Graphic Arts Ardealul] }\end{array}$ & 2 \\
\hline 10. & $\begin{array}{l}\text { Revista De Strajă [Magazine On Guard] [magazine of "The } \\
\text { Country's Guard" for the youth, București, 1938], Nr. 1/1939 } \\
\text { (3 vol.), Nr. 11-12/1938 (1 vol.) }\end{array}$ & 4 \\
\hline 11. & $\begin{array}{l}\text { Revista Străjerul [Magazine The Guardian], May-July-August } \\
\text { issues/1937 }\end{array}$ & 3 \\
\hline 12. & $\begin{array}{l}\text { Teofil Gh. Sidorovici, Carol II. Din culmea uni deceniu de } \\
\text { glorioasă domnie [Carol II. From the Height of a Decade of } \\
\text { Glorious Reign], București, } 1939\end{array}$ & 3 \\
\hline 13. & $\begin{array}{l}\text { C. I. Bondescu, Manual de limba germană cl. IV [Textbook for } \\
\text { German for the IV }{ }^{\text {th }} \text { grade] [București: Cultura Românească] }\end{array}$ & 1 \\
\hline 14. & $\begin{array}{l}\text { C. I. Bondescu, Emil Flavian, Manual de limba germană pentru } \\
\text { cl. VI de băieți și fete [Textbook for German for the VI } I^{\text {th }} \text { grade } \\
\text { boys and girls] [București: Cultura Românească] }\end{array}$ & 1 \\
\hline 15. & $\begin{array}{l}\text { I. Găvănescul, Curs de pedagogie. Didactica generală. } \\
\text { Principii de educația inteligenței [Pedagogy Course. Genaral } \\
\text { Didactics. Principles of training the intelligence], București: } \\
\text { Editura Librăriei și Tipografiei Steinberg \& Fiul, } 1923\end{array}$ & 1 \\
\hline
\end{tabular}


Table 1. Periodical and non-periodical publishings withdrawn in the school year 1946-1947 from the library of "Ștefan cel Mare" high school Suceava.

On the $10^{\text {th }}$ of October 1946, principal Mihai Cărăușu informed the teaching staff that from the inventory of the teaching materials were going to be removed "political, geographical or historical maps which were outdated", and the books cleansed "must be burned based on a minutes". The remaining books were to be "extensively used" by students (Ministerul Educației Naționale 1946: 173-174). On the $16^{\text {th }}$ of November 1946 the School Inspectorate issues order nr. 19790 urging "immediate destruction of all the books cleansed from the public school libraries", complying with telegraphed order nr. 353125 from minister Voitec (Rotariu 1946a: 416), cleansing confirmed on the $19^{\text {th }}$ of November by the school librarian (Slevoca 1946: 414). On the $29^{\text {th }}$ of November 1946, the school inspectorate sent "for information and strict compliance", minister`s order nr. 366.533 dated November $23^{\text {rd }} 1946$ regarding "the destruction of the teaching textbooks approved for the previous school year" [1945-1946] unless they had received approval for the schoo year 1946-1947 (Rotariu 1946b: 320).

The department of secondary education from The Ministry of National Education demanded, by order nr. 12120 dated January $21^{\text {st }} 1947$, that "principals check again the school libraries, and that the form teachers urge the students to remove from their own bookcases the forbidden books and maps, in compliance with the regulations of the Allied Control Commission" (Direcțiunea Învăţământului Secundar 1947).

\section{Library cleansing after 1948}

The debut of the school year 1947-1948 was made under a new, national democratic regime. Supplying new textbooks, "unique and free" in due time, without charges for the "studious young deprived of financial means", riddance of maps which were "unsuitable or overused" and mural paintings which "stifle the atmosphere", the introduction of unique textbooks for Romanian history and geography as well as exerting control over students' private reading were the organisational issues for the new school year that had been transmitted to all the teacher by the Ministry of National Education through order 228.569/1947. One important measure regarded the school library and the class libraries, which were to be checked and "completed with writings printed mainly in democratic publishing 
houses". Simultaneously, it was demanded that "pedagogical and documentary libraries for the teaching staff" be set up" (Voitec 1947: 356-360).

On the $30^{\text {th }}$ of September 1947, through address nr. 1689/1947, the Culture Department within the Ministry of Information Bucuresti, demanded to be sent the titles and the author names for all the volumes existing in the high school library. On grounds of a too short time span given the big number of volumes in the library, principal Alexandru Obadă sent to the ministry an overall report (Obadă 1947a: 243244). The unique texbooks necessary for the high school students were ordered on the 24th of November 1947. The table forwarded to the School Inspectorate by principal Alexandru Obadă, in compliance with order nr. 10908 dated the $20^{\text {th }}$ of November 1947, comprised textbooks for the following subjects: History for classes I-III and V-VII (215 volumes), Geography for classes III-IV and VIII (68 volumes), Russian language ALRUS for classes V-VIII (67 volumes), Political Economics for the VII grade by Zaharescu (59 volumes), Sociology for the VII ${ }^{\text {th }}$ grade by StahlVoinea (39) volumes, Law for the III ${ }^{\text {rd }}$ grade by de Broșteanu-Orescu (65 volumes) and Law for the VIII ${ }^{\text {th }}$ grade by Zaharescu (24 volumes) (Obadă 1947b: 33-35).

After king Mihai's forced abdication on the $31^{\text {th }}$ of December 1947, all the high school teachers had to take an oath, before the $2^{\text {nd }}$ of January 1948 (Ițcuş 1948a: 414). Classes resumed on the $8^{\text {th }}$ of January and during the first two lessons the students were briefed on the "abdication of the former king and the triumph of the Popular Republic of Romania" (Obadă 1948b: 377). The portraits of the royal family were removed from classes and burned, a minutes of the proceeding being drafted. The high school was renamed as The Boys' Theoretical High School Nr. 1, the name "Ștefan cel Mare" bing replaced with a number. "Romanian People's Republic" was introduced.

The cleansing of the high school's library was initiated on the basis of the Education Ministry order nr. 327552 from 1947. Regulations from governing bodies in this domain succeeded quickly. The books that made "total reference to a member of the former royal dynasty" were to be withdrawn from the library and kept in the principal's office (Ițcus 1948a: 414). On the $3^{\text {rd }}$ of January 1948, the portraits and paintings of the royal family were destroyed, in compliance with the order 327552/1947 issued by the Ministry of National Education: "Mihai I" (20 paintings), "Queen-Mother Elena" (17 paintings), "Carol I" (5 paintings), "Ferdinand I" (5 paintings), "The Royal Family" (5 paintings) (Obadă 1948a: 416).

After a new checking of the books from the students' library and the teachers' library, the books which mentioned the former royal dynasty were removed on the $8^{\text {th }}$ of January 1948 and sent for safekeeping in the principal's office. The form teachers, the teachers and the school librarian Reveca Slevoca, were instructed to remove "wherever the case may be, from different books, the portraits 
of the former royal family members or poems dedicated to this family, etc." (Obadă 1948d: 417). The minutes regarding the "burning of the royal paintings and the removal of the texts with dynastic content from books and textbooks" were forwarded to the Suceava Regional School Inspectorate on the $21^{\text {st }}$ of January 1948 by principal Obadă, in response to the Inspectorate order nr. 21175 from the $2^{\text {nd }}$ of January 1948 (Obadă 1948c: 415). Books "about the Peace treaty", the minutes and the catalogue of the removed books were sent to the Culture Council of Suceava County headquarters in Suceava, in compliance with the mandatory order nr. 692 from the $28^{\text {th }}$ of February 1948 (Consilieratul Cultural al Județului Suceava 1948a: 672). "All the portraits of the former royal family were blackened out in textbooks", as requested by order nr. 20713 from the $15^{\text {th }}$ of March 1948 from the Ministry of Education, forwarded by the Regional School Inspectorate Suceava with order nr. 4039/1948 (Ițcuș 1948b: 532). On the $5^{\text {th }}$ of October 1948, principal Alexandru Obadă and libraian teacher Reveca Slevoca handed to the Suceava County Cultural Council the volume Carmen Sylva. Prima Regină a României [Carmen Sylva. The First Romanian Queen] by Lucreția Carandino-Platamona [București: Publishing House of "Universul" Magazine, 1936], in compliance with order nr. 21117 dated the $5^{\text {th }}$ of April 1948. The book, which had been lent on the $16^{\text {th }}$ November 1946 to student Groznovschi from the $\mathrm{V}^{\text {th }}$ grade at the Girls' Theoretical High School, was taken to Czechoslowakia and returned when the student came back to sit her exams for the high school entrance exams (Obadă 1948e: 177).

The introduction of communist censorship in libraries through the decision of the Ministerial Council nr. 1542, published in the "Official Bulletin" nr. 20 from the $29^{\text {th }}$ of December 1951 had far reaching consequences. The removal of valuable books belonging to the Romanian cultural heritage restricted the readers' access to information. The cleansing of books deemed as "legionary, fascist, chauvine, natzi" or which contained fragments "harmful for the good relationship between Romania and The United Nations" (Ministerul Propagandei 1945: 3701-3702) was made based on the lists published in the Official Gazettes from 1948, the brochures "Publishings removed by the $1^{\text {st }}$ of August 1945", "Publishings forbidden by the $1^{\text {st }}$ of May [or the $1^{\text {st }}$ of November] 1948" (Caravia 2000: 13-14), as well as the lists and orders issued by censorship directors along the years (Regneală 1997: 116-123).

"The assessment" of the literary inheritance from the Stalinist epoch (19481964) required a new inventory and a reorganisation of the school library. Special collections, built in the basement walls of the heritage building during the war, were brought to light in those times in order to be saved. These events took place in the summer of 1960, under the leadership of retired teacher Brătianu, librarian teacher Filomela Ianovici (1957-1977) and voluntary students from the upper classes of the school (Ignat 2010: 377). The collections, gathered under the heading documentary 
fund [Fund "D" (1)] were immediately checked and censored. Minutes nr. 3 drafted on the $28^{\text {th }}$ of April 1961 mentioned 16 books cleansed from the documentary fund, in compliance with instructions nr. 3406 dated October 13 $3^{\text {th }}$ 1960: Dumbravă Bucura - Ceasuri sfinte [Holy Hours], Bucureşti, 1921; Petrovici Ion - Raite prin ţară [Wanderings throughout the Country], Bucureşti, 1944; Eminescu Mihail - Poezii [Poems], Bucureşti, 1937; Istoria filosofiei moderne. Omagiu prof. Ion Petrovici [History of Modern Philosophy. Homage to prof. Ion Petrovici], 1-4, Bucureşti, 1937-1939; Titu Maiorescu - Discursuri parlamentare [Parliamentary Speeches], 2, Bucureşti 1897; Ion Petrovici - Alexandru Philippide în evoluţia culturii româneşti -discurs [Alexandru Philippide and the Evolution of Romanian Culture - a speech], Bucureşti, 1935; Gala Galaction - Răboji pe bradul verde [Etching on the Green Fir Tree], Iaşi, 1920; Gheorghe Cantacuzino-Grănicerul - Un caz de arivism feroce [A case of Ferocious Avarition], 1924; Aurel Morariu - La zece ani de la izbucnirea marelui război [Ten Years after the Outburst Of the Great War], Cernăuţi, 1924; Titu Maiorescu - Discursuri parlamentare [Parliamentary Speeches], 3, Bucureşti, 1899; Coudenhove-Kalergi Richard Nikolaus - Judenhass, Wien, 1937; Hodann Max, Sowjetunion gestern, heute, morgen: mit 70 Photographien, Berlin, 1931.

Book censorship continued in the school library by wiping away the marks left by the recent past events, after the death of Stalin on the $5^{\text {th }}$ of March 1953. 1945 volumes were withdrawn from current use, their value rising to 6425,67 lei (between 1957-1977), according to alphabetically ordered catalogues (published or closecircuit ones) and the instructions of the State Committee for Culture and Art Education and Culture department. Here are some of the titles mentioned: Cântece şi poezii despre Stalin [Songs and Poems about Stalin], 1948; Periodizarea istoriei U.R.S.S. în lumina invățăturii tovarăşului Stalin [Chronology of the History of the USSR in the Light of the Teachings of Comrade Stalin], 1952; Pe drumul belsugului [On the Road of Welfare] by Eusebiu Camilar, 1953; Bădiţa Stalin [Mister Stalin] by Otilia Cazimir, 1950; Sindicatele din Rusia prerevoluţionară [Unions in Prerevolutionary Russia] by Ştender, 1948; Lenin, marele organizator al statului sovietic [Lenin, the Great Organiser] by Vîşinski, 1945, Vom transforma pământul [We Shall Change the Earth] by Vasiliev, 1956; Momente din istoria P.C.R. [Moments in the History of the Romanian Communist Party], 1966; Materialismul istoric [Historical Materialism], 1967; Capitalismul ca sistem mondial [Capitalism as a World System] by Silviu Brucan, 1968; Microsociologia, o utopie reacţionară [Microsociology, a Reactionary Utopy] by Bahitov, 1959; Principalele forme şi mijloace ale agitaţiei politice de masă [The Main Forms and Means of Mass Political Turmoil], 1960 and so on.

Book purchases were politically determined. Besides works by classical Romanian and foreign writers, during this period of time the school library enriched 
with many technical books and obviously with political books, which were mandatory. Compared to the mid-war period and even that of Austro-Hungarian occupation, donations were virtually non-existent, as there were only 25 volumes at the value of 346,61 lei.

The events from December 1989 did not put an end to censorship. On the revolutionary background, book cleansing went on, 1758 volumes with a value of 8259,61 lei being removed, on grounds that their "content was outdated" and that "their political content was of no interest any longer". Up to 1995 the following were destroyed: the manifesto, the statute, the programme and the principles code of the Romanian Communist Party; the articles and speeches of Gheorghiu-Dej, Hruşciov, Chivu Stoica, Maurer; political reports, orders, state visits, the work of the two Ceaușescu.

\section{Conclusions}

An instrument of control of those in power, the institution of censorship was preventively introduced by the government in Vienna to counterbalance the development of the national feeling within the peoples of the Austro-Hungarian empire. The printed word and the library were targeted - a cultural establishment that could stock and spread information deemed dangerous for the safety of the empire. It was forbidden for the first Romanian high school in southern Bucovina founded in 1860 for the majoritarian Romanian population and financially supported by the Orthodox Church Fund - to purchase Romanian books printed in the Romanian Principates, and the approvals for textbooks conceived in Romanian after the Austrian curriculum were not granted or came with delay. Thus, the library with Romanian books was illegally initiated in Suceava, and the classes in Romanian were opened only 21 years after the founding of the high school. Having been set up only for the lower course, classes with tuition in Romanian were doomed to disappear from the very beginning. Their survival was due to the perseverance and excellent scientific preparation of the Romanian teachers and students.

Censorship continued in the following historical periods as well, the library being revised repeatedly: the removal of the books with "biased Austrian content" during the Russian occupation (1916-1918), the elimination of those that did not correspond "from a patriotic, religious and moral" perspective and the geography and history books "written to uphold the idea of the Austrian state and the education of our youth for this state" (1920); the interdiction of supplying the school with books and stationery published in Jewish publishing houses (1940); the ban on books by Jewish writers and those with "frivolous, unuseful content" written by other authors (1942); the revision of the German books and the removal of those 
which "in content do not comply with the country's political orientation", the withdrawal from public use of books, magazines, maps in which "Basarabia and northern Bucovina are shown within the borders of Romania", as well as various graphical or fine reproductions that "reflect badly on the good relationships between Romania and the United Nations" (1945); the burning of the royal paintings and the removal of "text with dynasty content from books and handbooks" (1948).

Book cleansing was made following the guidelines published between 19451948 , the lists and orders issued by censorship headmasters. Censorship was present all along the communist period, and in 1953 it went on to wipe away the traces of the recent past of the political leaders. It did not stop in 1989 when, given the euphoria resulted from the historic event, the books with "outdated content" and "political publishings of no interest any longer" were eliminated.

We owe the salvation of the special collections from the library at Colegiul Naţional "Ștefan cel Mare" Suceava to interim headteacher Aurel Buleandra, senior teacher of PE and, who decided in 1944 to "bury" the books and to headteachers Mihai Cărăușu (1945-1947), Alexandru Obadă (1947-1951, 1955-1967), Nicodim Ițcuș (1951-1953) and Ilie Rotaru (1953-1955), who did not rush "to unearth" them, in order to allow the fury of the cleansing started by the new regime to calm down.

\section{Notes}

1. The English translation was made by Mrs. Elisabeta Bucaciuc-Mracica, teacher at Colegiul Național ,Ștefan cel Mare" Suceava

2. Although at odds with "the aims of socialist education" imposed by the new political regime, the books and periodicals included in the documentary fund, indispensable for scientific research, could be accessed "only with unavoidable justifications and approvals".

\section{References}

Buleandră, A. (1945) Proces-verbal $n r$. 5/13.04.1945 [Minutes $n r .5 / 13^{\text {th }}$ April $1945]$ [record] Collection Liceul "Ștefan cel Mare" (further on referred to as L.S.C.M.). Suceava: Suceava County Service of National Archives (further on referred to as S.J.A.N.), Record 1/1944, 10-12

Burduhos, V. (1919) Proces verbal nr. 4/3.02.1919 [Minutes $n r .4 / 3^{\text {rd }}$ February 1919] [manuscript] L.S.C.M.. Suceava: S.J.A.N., Record 3/1919, 4

Burduhos, V. (1922a) Proces-verbal $n r .6 / 18.12 .1922$ [Minutes $n r .6 / 18^{\text {th }}$ December 1922 ] [manuscript] L.S.C.M. Suceava: S.J.A.N., Record 3/1922, 12-13

Burduhos, V. (1922b) "Raport asupra anului școlar 1921-1922". Anuarul Liceului ort. or. "Ștefan cel Mare" in Suceava publicat la finele anului școlar 19211922 de Vasile Burduhos, director [The Yearly Book ort. or. "Ștefan cel 
Mare" High school in Suceava published at the end of the school year 1921/22 by the principal Vasile Burduhos]. Suceava: Tipografia "Școala Română" 32

Burduhos, V. (1923) Proces-verbal $n r$. 23/30.06.1923 [Minutes $n r .23 / 30^{\text {th }}$ June 1923] [manuscript] L.S.C.M. Suceava: S.J.A.N., Record 3/1922, 48

Burduhos, V. (1938) "Raportul directorului". Anuarul Liceului "Ștefan cel Mare" Suceava publicat la finele anului școlar 1936/37 de Vasile Burduhos, directorul liceului [Yearly Book of "Ștefan cel Mare" High school from Suceava, published at the end of the school year 1936/37 by Vasile Burduhos, school principal]. Suceava: Tipografia Hermann Beiner, 25

Cărăușu, M. (1945a) Proces-verbal nr. 13/2.12.1945 [Minutes $n r .13 / 2^{\text {nd }}$ December 1945] [record] Collection Liceul "Ștefan cel Mare". Suceava: S.J.A.N., Record 6/1945, 8

Cărăușu, M. (1945b) Dare de seamă asupra activității desfășurate la Liceul "Ștefan cel Mare” Suceava in cursul anului şcolar 1944-1945 [Report on the activities held at Liceul "Ștefan cel Mare" Suceava in the school year 19441945] [record] L.S.C.M. Suceava: S.J.A.N., Record 6/1945, 2-3

Cărăușu, M. (1945c) Proces-verbal nr. 26/30.10.1945 [Minutes $n r .26 / 30^{\text {th }}$ October $1945]$ [record] L.S.C.M. Suceava: S.J.A.N., Record 8/1945, 74

Cărăușu, M. (1945d) Adresa nr. 677/28.09.1945 către Inspectoratul Școlar al Regiunii Suceava [Address nr.677/28 $8^{\text {th }}$ November 1945 to the Regional School Inspectorate Suceava] [correspondence] L.S.C.M. Suceava: S.J.A.N., Record 39/1945, 599

Cărăușu, M. (1946) Tabloul publicațiilor periodice și neperiodice retrase [Table of withdrawn periodical and nonperiodical publishings] [manuscript] L.S.C.M. Suceava: S.J.A.N., Record 1/1946, 144-145

Caravia, P. (2000) Gândirea interzisă: scrieri cenzurate: România 1945-1989 [Forbidden thinking. Censored written works. România 1945-1989]. București: Editura Enciclopedică, 13-14

Consilieratul Cultural al Județului Suceava (1948a) Adresa nr. 692/28.02.1948 către biblioteca Liceului "Ștefan cel Mare" Suceava [Address $n r$. 692/28 th February 1948 to the Library of the Boy's High School "Ștefan cel Mare" Suceava] [correspondence] L.S.C.M. Suceava: S.J.A.N., Record 5/1947, 672

Consiliul școlar al țării Bucovina ([1806, 1896] 1918) Legi disciplinare pentru Școalele Medii ale Bucovinei [Disciplinary Rules for Middle Schools in Bucovina]. Cernăuți: Tipografia universității R. Eckhardt, 8 [original] L.S.C.M. Suceava: S.J.A.N., Record 1/1922 
Consiliul Școlar al Țării (1919a) Adresa nr. 2787/28.05.1919 către Direcțiunile tuturor școalelor secundare publice și particulare [Address $n r .2787 / 28^{\text {th }}$ May 1919 to all the school boards from public and private secondary schools] [correspondence] L.S.C.M. Suceava: S.J.A.N., Record 1/1919, 274

Consiliul Școlar al Țării (1919b) Adresa nr. $4203 / 1919$ din 21.01.1920, către direcțiunile tuturor școalelor secundare [Address $n r$. 4203/1919/21 ${ }^{\text {st }}$ January 1920 to all the school boards from secondary schools] [correspondence] L.S.C.M. Suceava: S.J.A.N., Record 1/1920, 53

Consiliul Școlar al Țării (1920) Adresa nr. 13077/28.11.1920, către Direcțiunile tuturor școalelor secundare și asimilate publice și particulare [Address $n r$. 13077/28 $8^{\text {th }}$ November 1920 to all the secondary school boards from public and private secondary schools]. [correspondence] L.S.C.M. Suceava: S.J.A.N., Record 1/1920, 550

Direcția Învăţământului Secundar (1940a) Adresa nr. 190.948/B/octombrie 1940 [Address $n r$. 190.948/B dated October 1940] [correspondence] L.S.C.M. Suceava: S.J.A.N., Record 1/1940, 667

Direcția Învățământului Secundar (1940b) Adresa nr. 196.080/B din octombrie 1940 [Address $n r .196 .080 / B$ dated October 1940] [correspondence] L.S.C.M. Suceava: S.J.A.N., Record 1/1940, 686

Direcțiunea Învăţământului Secundar (1947) Adresa nr. 12120/21.01.1947, către Inspectoratul S,colar Regional Suceava [Address $n r$. 12120/21 $1^{\text {st }}$ January 1947 to the Regional School Inspectorate Suceava] [correspondence] L.S.C.M. Suceava: S.J.A.N., Record 4/1946.

Doroftei, G. (1945) Adresa Primăriei oraşului Suceava nr. 5242/23.08.1945 către Liceul „STtefan cel Mare” [Address $n r .5242 / 23^{\text {rd }}$ August 1945 from the Town Hall of Suceava to "Ștefan cel Mare" High School] [correspondence] L.S.C.M. Suceava: S.J.A.N., Record 39/1945, 16

Editura Cartea Românească București (1941a) Adresa nr. 72504/3.04.1941, către Direcțiunea Liceului "Ștefan cel Mare" Suceava [Address $n r .72504 / 3^{\text {rd }}$ April 1941, to the board of "Ștefan cel Mare" High School Suceava] [correspondence] L.S.C.M. Suceava: S.J.A.N., Record 3/1941, 227

Editura Cartea Românească București (1941b) Adresa nr. 306/22.02.1941, către Direcțiunea Liceului de Băieți "Ștefan cel Mare" Suceava [Address $n r$. 306/22 $2^{\text {nd }}$ February 1941, to the board of "Ștefan cel Mare" Boys' High School Suceava] [correspondence] L.S.C.M. Suceava: S.J.A.N., Record 3/1941, 118

Grămadă, I. (1946) Adresa Ministerului Informațiilor nr. 198/25.09.1946, către Direcțiunea Liceului "Ștefan cel Mare" Suceava [Address from the Ministry of Information $n r .198 / 25^{\text {th }}$ September 1946 to the board of "Ștefan cel 
Mare" Suceava High School] [correspondence] L.S.C.M. Suceava: S.J.A.N., Record 1/1946, 246-247

Grassauer, F. (1883) Handbuch für österreichische Universitäts- und StudienBibliotheken sowie für Volks-, Mittelschul- und Bezirks-Lehrerbibliotheken [Handbook for Austrian Universities and Study Libraries As Well As for Public Libraries, Secondary School Libraries and District Teacher Libraries]. Wien: Verlag von Carl Graeser

Grigorovici, A. (1946) Tabel nominal de elevii Liceului "Ștefan cel Mare" ce au predate manualele vechi [Table containing the names of the students from "S,tefan cel Mare" High School who handed in the old textbooks] [manuscript] L.S.C.M. Suceava: S.J.A.N., Record 1/1946, 139-143

Ienceanu, V. (1943a) Situația bibliotecilor liceului de băieți până la data de 31 martie 1943 [Situation of the libraries from the boys' high school up to the $31^{\text {st }}$ of March 1943] [record] L.S.C.M. Suceava: S.J.A.N., Record 2/1943, 171

Ienceanu, V. (1943b) Adresa nr. 3534/31.03.1943 către Directoratul Învățământului Cernăuți, [Address nr. 3534/31 $1^{\text {st }}$ March 1943 to the Department of Education Cernăuți] [correspondence] L.S.C.M. Suceava: S.J.A.N., Record 2/1943, 183

Ienceanu, V. (1943c) Proces-verbal nr. 1/5.07.1943 [Minutes nr. 1/5 th July 1943] [record] L.S.C.M. Suceava: S.J.A.N., Record 32/1943, 3

Ienceanu, V. (1945a) Proces-verbal $n r$. 2/10.02.1945 [Minutes $n r .2 / 10^{\text {th }}$ February 1945] [record] L.S.C.M. Suceava: S.J.A.N., Record 1/1944, 6

Ienceanu, V. (1945b) Adresa nr. 907/10.02.1945, către Domnul Inspector General Administrativ Suceava [Address nr. 907/10 th February 1945 to the Head Administrative Inspector] [correspondence] L.S.C.M. Suceava: S.J.A.N., Record 16/1944, 121

Ienceanu, V. (1945c) Raportul General nr. 1699 din mai 1946 asupra mersului Școalei in anul școlar 1944-1945 [Overall Report nr. 1699 dated May 1946 on the School's activity in the school year 1944-1945] [record] L.S.C.M. Suceava: S.J.A.N., Record 6/1945, 32

Ieremie, N. (1945) Adresa Poliției de Reședință Suceava nr. 725/17.01.1945 către Liceul de băieți "Ștefan cel Mare" Suceava [Address of the Suceava Police Headquarters $n r .725 / 17^{\text {th }}$ January 1945 to the Boys' High "S,tefan cel Mare” Suceava] [correspondence] L.S.C.M. Suceava: S.J.A.N., Record $16 / 1944,65$

Ieșan, M. (1942) Adresa Directoratului Învățământului şi Cultelor Cernăuţi nr. 26407/24.07.1942 [Address of the Department of Education and Cults 
Cernăuți $n r .26407 / 24^{\text {th }}$ July 1942] [correspondence] L.S.C.M. Suceava: S.J.A.N., Record 28/1942, 24

Ignat, M. (2010) "Gânduri după jumătate de veac". Când amintirea începe să vorbească... ["Musings after a Half a Century". When Memories Start Speaking...], ed. Rodica Belța, Suceava: Muşatinii, 377

Inspectoratul XIV Regional Cernăuți (1927) Adresa nr. 25327/8.12.1927, tuturor direcțiunilor școalelor secundare [Address $n r .25327 / 8^{\text {th }}$ December 1927 to all the boards of secondary schools] [correspondence] L.S.C.M. Suceava: S.J.A.N., Record 1/1927, 1017

Ițcuș, N. (1945) Adresa Inspectoratului școlar regional Suceava $n r$. 16124/15.11.1945, tuturor școalelor secundare din regiune [Address of the Regional School Inspectorate Suceava nr. 16124/15 th November 1945 to all the secondary schools in the region] [correspondence] L.S.C.M. Suceava: S.J.A.N., Record 39/1945, 598

Ițcuș, N. (1948a) Adresa Inspectoratului Școlar Regional Suceava $n r$. 21175/2.01.1948, tuturor școalelor de grad secundar din regiune [Address of the Regional School Inspectorate Suceava nr. 21175/2 ${ }^{\text {nd }}$ January 1948 to all the secondary schools in the region] [correspondence] L.S.C.M. Suceava: S.J.A.N., Record 4/1947, 414

Ițcuş, N. (1948b) Adresa Inspectoratului Școlar Regional Suceava $n r$. 4039/15.03.1948, tuturor școalelor de grad secundar [Address of the Regional School Inspectorate Suceava nr. 4039/15 th March 1948 to all the secondary schools in the region] [correspondence] L.S.C.M. Suceava: S.J.A.N., Record 5/1947, 532

Limberger, J. (1872) "Schulnachrichten". Programm des griech.-orient. OberGymnasiums in Suczawa für das Schuljahr 1872. Herausgegeben von dem Director des Gumnasiums Joh. Limberger [Programme of the Greek-orient. Upper Gymnasium in Suczawa for the School Year 1872. Edited by the Gymnasium Principal Joh. Limberger]. Czernowitz: Buchdruckerei des Rudolf Eckhardt, 71

Ministerium für Cultus und Unterricht in Wien (1883) "Erlass des Ministers für Cultus und Unterricht vom 3. Jänner 1883, Z. 13456 ex 1882" [Decree of the Minister of Cults and Teaching Service from the 3rd January 1883, Nr. 13456 ex 1882]. Verordnungsblatt für den Dienstbereich des Ministeriums für Cultus und Unterricht. Jahrgang 1883 [Orders of the Ministry of Cults and Teaching Service. Year 1883]. Wien: Verlag des k. k. Ministeriums für Cultus und Unterricht, 6 
Ministerul Educației Naționale (1946) Ordinul $n r$. 311.100/A/946 [Order $n r$. 311.100/A/946] [correspondence] L.S.C.M. Suceava: S.J.A.N., Record 1/1946, 173-174.

Ministerul Propagandei (1945). "Decret-Lege nr. 364 din 2 mai 1945 pentru retragerea unor anumite publicaţiuni periodice și neperiodice, reproduceri grafice și plastice, filme, discuri, medalii și insigne metalice" [Decree nr. 364 dated the $2^{\text {nd }}$ of May 1945 for the withdrawal of certain periodical and non-periodical publishings, graphical and artistic reproductions, films, records, medals and metal badges]. Monitorul Oficial al României: Partea Ia 4 May, CXIII (102), 3701-3702

Morariu, C. (1889) Biografi'a lui Constantin Morariu Andrieviciu, fostu profesoru ord[inariu] de teologi'a morala la institutulu teologicu din Cernautiu scrisa de Unu adêncu stimatoriu a dênsului [Constantin Morariu Andrievici's biography, former teacher of theological dogma at the Theological Institute from Cernautiu compiled by one of his admirers]. Gherl'a: Tipografi'a "Aurora" P. A. Todoranu

Nistor, I. (1991) Istoria Bucovinei [The History of Bukowina]. București: Humanitas, 149

Obadă, A. (1947a) Adresa nr. 242/14.10.1947, către Ministerul Informațiilor [Address $n r .242 / 14^{\text {th }}$ October 1947 to the Ministry of Information] [correspondence] L.S.C.M. Suceava: S.J.A.N., Record 3/1947, 243-244

Obadă, A. (1947b) Adresa nr. 474/27.11.1947, către Inspectoratul Școlar Regional Suceava, [Address nr. 474/27 th November 1947 to the Regional School Inspectorate Suceava] [correspondence] L.S.C.M. Suceava: S.J.A.N., Record 3/1947, 33-35

Obadă, A. (1948a), Proces verbal din 3 ianuarie 1948 [Minutes dated the $3^{\text {rd }}$ of January 1948] [record] L.S.C.M. Suceava: S.J.A.N., Record 4/1947, 416

Obadă, A. (1948b) Adresa nr. 737/12.01.1948, către Inspectoratul Școlar Regional Suceava [Address $n r .737 / 12^{\text {th }}$ January 1948 to the Regional School Inspectorate Suceava] [correspondence] L.S.C.M. Suceava: S.J.A.N., Record 4/1947, 377

Obadă, A. (1948c) Adresa nr. 716/21.01.1948, către Inspectoratul Școlar Regional Suceava, [Address $n r .716 / 21^{\text {st }}$ January 1948 to the Regional School Inspectorate Suceava] [correspondence] L.S.C.M. Suceava: S.J.A.N., Record 4/1947, 415

Obadă, Al. (1948d) Proces verbal din 8 februarie 1948 [Minutes dated the $8^{\text {th }}$ of February 1948] [record] L.S.C.M. Suceava: S.J.A.N., Record 4/1947, 417

Obadă, A. (1948e) Adresa din 5 octombrie 1948, către Consilieratul Cultural Județean Suceava [Address dated the $5^{\text {th }}$ of October 1948 to the County 
Culture Department Suceava] [correspondence] L.S.C.M. Suceava: S.J.A.N., Record 1/1948, 177

Petcu, M. (coord.) (2016) O cronologie a cenzurii în România [A chronology of censorship in Romania]. București: Tritonic, 7

Popovici, E. (1935) Din istoricul Liceului Ștefan cel Mare din Suceava. 1860-1935 [From the History of Ștefan cel Mare High school from Suceava, 18601935]. Suceava: Societatea Școala Română

Prefectura Județului Suceava (1945a) Adresa Biroului Armistițiului $n r$. 2229/17.02.1945, tuturor serviciilor publice [Address from the Truce Biureau $n r .2229 / 17^{\text {th }}$ February 1945 to all the public services] [correspondence] L.S.C.M. Suceava: S.J.A.N., Record 1/1945, 19

Prefectura Județului Suceava (1945b) Adresa Biroului pentru aplicarea Armistițiului nr. 373/24.08.1945 către Liceul "Ștefan cel Mare" Suceava [Address from the Truce Enforcement Biureau nr. 373/24 th of August 1945 to "Ștefan cel Mare" High School Suceava] [correspondence] L.S.C.M. Suceava: S.J.A.N., Record 1/1945, 19

Primăria Orașului Suceava (1942) Adresa nr. 9219/11.12.1942, către Liceul "Ștefan cel Mare" Suceava [Address $n r$. 9219/1 th $^{\text {th }}$ December 1942 to "Ștefan cel Mare" High School Suceava] [correspondence] L.S.C.M. Suceava: S.J.A.N., Record 24/1942, 205

Regneală, M. (1997) "Legislaţia românească de bibliotecă în perioada 1948-1989" ["Romanian Library Legislation between 1948-1989"]. Studii de Biblioteconomie și Știința Informării / Library an Information Science Research [online] 3, 116-123. Available from < http://www.lisr.ro/3.html> [16 June 2019]

Repta, S. (1906) "Schulnachrichten“. Jahres-Bericht des gr.-or. Ober-Gymnasiums in Suczawa, veröffentlicht am Schlusse des Schuljahres 1905-1906 [Annual report of the Gr. Or. Upper Gymnasium in Suczawa, published at the end of the school year 1905-1906]. Suczawa: Buchdruckerei Hermann Beiner, 1-2, 33

Rotariu, I. (1946a) Adresa Inspectoratului școlar Regional Suceava $n r$. 19790/16.11.1946, tuturor școlilor de grad secundar și gimnaziilor unice şi inspectoratelor școlare județene [Address from the Regional School Inspectorate Suceava $n r .19790 / 16^{\text {th }}$ November 1946 to all the secondary schools and middle schools and county school inspectorates] [correspondence] L.S.C.M. Suceava: S.J.A.N., Record 2/1946, 416

Rotariu, I. (1946b) Adresa Inspectoratului școlar regional Suceava $n r$. 20725/29.11.1946, tuturor școalelor de grad secundar și gimnaziilor unice [Address of the Regional School Inspectorate Suceava $n r .20725 / 29^{\text {th }}$ 
November 1946 to all the secondary schools middle schools] [correspondence] L.S.C.M. Suceava: S.J.A.N., Record 2/1946, 320

Secretariatul de Serviciu pentru Instrucțiunea Publică (1919) Adresa $n r$. 551/3.05.1919, tuturor Direcțiunilor școalelor secundare și asimilate din țară [Address $n r .551 / 3^{\text {rd }}$ May 1919 to all the secondary school boards in the country] [correspondence] L.S.C.M. Suceava: S.J.A.N., Record 1/1919, $15-22$

Slevoca, R. (1945) Înștiințtare de retragere din circulație a cărților identificate conform listei $n r$. 9-13 [Notification for the withdrawal from use of books identified according to list $n r$. 9-13] [manuscript] L.S.C.M. Suceava: S.J.A.N., Record 39/1945, 391

Slevoca, R. (1946) Referat din 19 noiembrie 1946, incheiat la Biblioteca Liceului "SStefan cel Mare" Suceava [Report dated the $19^{\text {th }}$ of November 1946, drafted at the Library of Ștefan cel Mare" High School] [manuscript] L.S.C.M. Suceava: S.J.A.N., Record 2/1946, 414

Vișan, I. (1942a) Adresa Directoratului Învățământului și Cultelor Cernăuți nr. 41023/5.11.1942 [Address from the Department of Education and Cults Cernăuţi $n r .41023 / 5^{\text {th }}$ November 1942] [correspondence] L.S.C.M. Suceava: S.J.A.N., Record 24/1942, 63

Vișan, I. (1942b) Adresa Directoratul Învățământului și Cultelor Cernăuţi $n r$. 42928/19.11.1942 [Address from the Department of Education and Cults Cernăuți $n r .42928 / 19^{\text {th }}$ November 1942] [correspondence] L.S.C.M. Suceava: S.J.A.N., Record 24/1942, 133

Voitec, S. (1945) Ordinul Ministerului Educației Naționale nr. 227018/1945 cuprinzând dispozițiunile pentru anul școlar 1945/1946 [Order Issued by the Ministry of National Education nr. 227018/1945 comprising the regulations for the school year 1945/1946] [correspondence] L.S.C.M. Suceava: S.J.A.N., Record 39/1945, 59, 61

Voitec, S. (1947) Circulara Ministerul Educației Naționale nr. 228.569/1947 [Memorandum from the Ministry of National Education $n r$. 228.569/1947] [correspondence] L.S.C.M. Suceava: S.J.A.N., Record 3/1947, 356-360 